\title{
Disparity in Health Care Utilization by Income Level and Insurance Status at Gamping Muhammadiyah Hospital, Yogyakarta, Indonesia
}

\author{
R. Haryo Nugroho'), Bhisma Murti'), Arif Suryono²) \\ ${ }^{1)}$ Masters Program in Public Health, Universitas Sebelas Maret \\ 2)Faculty of Law, Universitas Sebelas Maret
}

\begin{abstract}
Background: Ideal equity in health is defined as each individual has the same opportunity to get the best health and not be harmed in the process of obtaining the health services. Communities with different socio-economic status should receive the same health services according to their needs, including equal access rights in the utilization of health services. Nowadays, the quality health services cannot be enjoyed equally by the Indonesian. The purpose of this study was to examine disparity in health care utilization by income level and insurance status at Gamping Muhammadiyah Hospital, Yogyakarta, Indonesia.

Subjects and Method: This study was an observational analytic study with a cross-sectional design. The study was conducted at PKU Muhammadiyah Gamping Hospital, Sleman Yogyakarta. 200 subjects were selected using simple random sampling. The dependent variable was the frequency of use of health services. The independent variables were the health insurance (BPJS) status, patient income, patient education level, and residence. The data were collected by questionnaire and analyzed by a multiple linear regression.

Results: Frequency of health care utilization decreased with health insurance membership status $(b=-4.49 ; 95 \% \mathrm{CI}=-1.53$ to $-0.60 ; \mathrm{p}<0.001)$ and longer distance $(\mathrm{b}=-7.33 ; 95 \% \mathrm{CI}=-0.07$ to $0.04 ; \mathrm{p}<0.001)$. Frequency of health care utilization increased with patient age $(\mathrm{b}=10.20 ; 95 \% \mathrm{CI}=$ 0.06 to $0.09 ; \mathrm{p}<0.001)$, family income $(\mathrm{b}=3.30 ; 95 \% \mathrm{CI}=0.00$ to $0.01 ; \mathrm{p}=0.001)$, and residence $(\mathrm{b}=3.11 ; 95 \% \mathrm{CI}=0.33$ to $1.47 ; \mathrm{p}=0.002)$.

Conclusion: Frequency of health care utilization decreases with health insurance membership status and longer distance. Frequency of health care utilization increases with patient age, family income, and residence.
\end{abstract}

Keywords: disparity, health insurance

\section{Correspondence:}

R. Haryo Nugroho. Masters Program in Public Health, Universitas Sebelas Maret. Jl. Ir. Sutami 36A, Surakarta 57126, Central Java, Indonesia. Email: haryo_sleman@yahoo.co.id.

\section{BACKGROUND}

Many countries around the world are very interested in implementing the idea of Universal Health Coverage (UHC) as a driving force to support the government to achieve good health goals for everyone. It is because the more the number of sick people, the more they need effective medical services, and increased investment is needed to meet the demand for improved medical infrastructure and improved highquality medical services.

Indonesia is one of the countries that has begun to use a national health scheme under the name Health Insurance (JK) designed for health services to all its population with a membership coverage of 255 million by the end of 2019. Although Indonesia has made steady progress, about one third of the permanent population issued widespread health payments, even among health insurance members. To help close 
this gap, especially among the poor, the Indonesian government is currently implementing a series of universal health coverage policy reforms that include the integration of the remaining government insurance schemes into health insurance, provider network expansion, system provider payment restructuring, accreditation of all contracted and various health facilities demand side initiatives to increase insurance absorption, especially in the informal sector (Thabrany et al. 2018).

Health Insurance is an amalgamation of four general insurance schemes (Askes insurance for PNS, Jamkesmas insurance for the poor, Jamsostek insurance for private sector workers and Asabri as Insurance for the armed forces and Taspen). JK is designed to provide high-quality health services that are fair and by strengthening primary care to hospitals.

Health insurance emphasizes primary care and increases the procurement, distribution and use of medicines. Its main objectives include increasing equity access to health services, improving health, and keeping health costs down. Efforts to achieve universal health services, especially in poor and remote areas, will require effective health promotion and expansion of quality health services for all Indonesian people. Given the diverse geography and economic status across the country, a comprehensive assessment of disparate gaps in morbidity, mortality and disability patterns and their causes is urgently needed (Mboi et al. 2018).

BPJS Health Insurance Participants are divided into Contribution Beneficiary (PBI) and Non-Contribution Assistance Recipients (Not PBI) categories which are divided into three classes including $\mathrm{JK}$ BPJS Class 1, JK BPJS Class 2, JK BPJS Class 3 (Ministry of Health, 2013).
Equity is an ideal, fair, and not partial position (Sen, 1999). Equity in health shows that ideally everyone has a fair chance to get the best health and not be harmed in obtaining health services.

Currently health services had not been enjoyed equally by the population of Indonesia. This happens because there were several differences such as geographical distance, educational background, beliefs, socio-economic status, and lack of health insurance coverage. Health care is inseparable from health financing, because in times like today what if we seek treatment at a hospital or to a specialist will definitely cost money, which sometimes costs a high cost of treatment.

People with chronic non-communicable diseases (NCDs) are very vulnerable to health injustices due to long-term health care needs and often become expensive, compounded by the inability to earn more money (Xie et al. 2014).

A study on inequality in health services was also carried out by Nababan et al. (2018) which shows that from 1986 to 2012, the institutional birth rate increased from $22 \%$ to $73 \%$. There are inequities in access to health based on income, education of parents, area of residence, and geographical area. Urban women are 3 times more likely to use health facilities than rural women. The use of all services is higher in Java and Bali than in other regions.

Hypertension or high blood pressure is a condition where there is an increase in blood pressure above the normal threshold of $120 / 80 \mathrm{mmHg}$. According to the WHO (Word Health Organization), the blood pressure limit that can be considered normal is less than $130 / 85 \mathrm{mmHg}$. If the blood pressure is more than $140 / 90 \mathrm{mmHg}$ in adults aged 18 years it is stated as hypertension (Adib, 2009). 
2015 WHO data shows that around 1.13 billion people in the world suffer from hypertension. In Indonesia, based on data from the Basic Health Research (Riskesdas) of Balitbangkes in 2018, the national prevalence of hypertension rose from $25.8 \%$ to 34.1\% (Indonesian Ministry of Health, 2018). Based on integrated surveillance of Puskesmas disease in 2017, there were 20,309 cases of hypertension, and for integrated surveillance of outpatient diseases Hospital there were 12,962 new cases that occurred in DI Province Yogyakarta (DIY Provincial Health Office, 2017). Based on preliminary surveys that have been carried out, it is known that hypertension is included in the top 10 diseases in PKU Muhammadiyah Gamping hospital, Sleman.

The general objective of this study was to analyze the inequality of the use of health services in hypertensive patients participating in the BPJS Health Health Insurance at PKU Muhammadiyah Gamping Hospital, Sleman.

\section{SUBJECTS AND METHOD \\ 1. Study Design \\ The method used in this study was obser- vational analytic with cross sectional design. It was conducted at PKU Muham- madiyah Gamping Hospital, Sleman Yogyakarta, from April to June 2019.}

\section{Population and sampling}

The population in this study were hypertensive patients who used health services with health insurance facilities from the Health Insurance in PKU Muhammadiyah Gamping Hospital Sleman Yogyakarta.

The sample of this study was 200 patients, taken from BPJS Health Class 1 participants, Class 2 BPJS participants, Class 3 BPJS Health participants and BPJS Health Recipient Participants (PBI) participants selected using a simple random sampling technique.

\section{Study Variables}

This study consists of independent and dependent variables. The dependent variable in this study was the frequency of use of health services. Meanwhile, the independent variables in this study included the membership status of the Health BPJS, the age of the patient, family income, location of residence, distance traveled.

\section{Operational Definition of Variables}

The operational definition of the membership status of JK BPJS Health is the participation of patients in health insurance consisting of JK BPJS Health class 1 with premium contributions of Rp. 80,000 and class 1 inpatient facilities, JK 2JS Health class 2 membership with a contribution of Rp 51,000 and class 2 inpatient facilities, membership of class 3 BPJS Health with contributions of 25,500 and class 3 inpatient facilities, membership of BPJS Health Beneficiary Benefit (PBI) is defined as Participant BPJS Health Beneficiary Benefit (PBI) from the government and inpatient class 3 .

The age of the patient is the age of the patient when using health services.

Family income is the income in rupiah per month which is calculated from the average amount of fixed or non-fixed income received by the family each month divided by the number of family members.

Distance to health service was the distance between the hospital and the place of residence of patients using health services, measured in kilometers $(\mathrm{km})$.

Frequency of use of health services is the number of uses of health services in the past year.

\section{Instrument}

The instrument was a questionnaire that has been tested for validity. Membership status data for JK BPJS Health, age of patient, family income, location of residence, and distance of residence with 
health services in this study were obtained using questionnaires given to patients. The frequency of use of health services in this study was obtained from questionnaires, interviews, observations, and from medical record data on research samples.

\section{Data Analysis}

The data were analyzed using univariate, bivariate, and multivariate analysis. Univariate analysis was used to look at the frequency distribution and the percentage characteristics of the subjects. Bivariate analysis was conducted to study the relationship between sample characteristics. Bivariate analysis was used to determine the relationship between frequency of use of health services and independent variables using one way ANOVA test, $\mathrm{t}$ test, and Pearson product moment. Meanwhile, multivariate analysis was using linear regression analysis was used to determine the effect of the dependent variable with independent

\section{Table 1. Subjects Characteristics}

\begin{tabular}{lcccc}
\multicolumn{1}{c}{ Subjects Characteristics } & Criteria & Mean & n & (\%) \\
\hline Gender & Male & & 117 & 58.5 \\
& Female & & 83 & 41.5 \\
Educational & Senior high school & & 77 & 35.5 \\
Residence & Rural & & 83 & 41.5 \\
& Urban & & 117 & 58.5 \\
Age & & 50,87 & & \\
Family income & & $2,885,000$ & & \\
Distance $(\mathrm{km})$ & & 13.6 & & \\
Frequency of health services uptake & & 5.45 & \\
\hline
\end{tabular}

\section{BivariateAnalysis}

Bivariate analysis was used to analyze the influence between BPJS health insurance

Table 2. Results of Bivariate Analysis

\begin{tabular}{rcc}
\hline Variable & $\mathbf{r}$ & $\mathbf{p}$ \\
\hline BPJS health insurance status & 111.813 & $<0.001$ \\
\hline
\end{tabular}

Table 2 showsed that there was a significant difference between the membership status of BPJS health insurance and frequency of variables, external variables with dependent variables and external variables with independent variables.

The number of samples obtained and fulfilling the inclusion and exclusion criteria were 200 patients as respondents. The characteristics of the respondents in this study are illustrated in Table 1. subject of the study consisted of 117 (58.5\%) men, and 83 (41.5\%) women. The average age of patients is 50.87. The education level school, which is $77(35.5 \%)$. The average income level is Rp. 2,885,000. The residence location consisted of 117 (58.5\%) and 83 (41.5\%). The average distance of the patient is $13.36 \mathrm{~km}$. The average frequency of use of health services is 5.45 times a year.

\section{UnivariateAnalysis}

Table 1 shows that gender as the of the majority of respondents is high 
Table 3. Differences in age and place of residence on the frequency of use of health services

\begin{tabular}{ccccc}
\hline Independent & \multirow{2}{*}{$\mathbf{b}$} & \multicolumn{2}{c}{$\mathbf{9 5 \%}$ CI } & \multirow{2}{*}{ Variable } \\
\cline { 3 - 4 } & -2.97 & Lower limit & Upper limit & \\
\hline Age & -2.58 & -5.22 & 0.003 \\
Residence & -11.61 & -4.51 & -3.20 & $<0.001$ \\
\hline
\end{tabular}

Table 3 shows that there was a significant difference between the age of the patient and the value $(\mathrm{b}=-2.97 ; 95 \% \mathrm{CI}=-2.58$ to $5.22 ; \mathrm{p}=0.003$ ), and the location of resi-

Table 4. The effect of the distance on the income to the frequency of health service utilization

\begin{tabular}{lcc}
\hline \multicolumn{1}{c}{ Independent Variable } & $\mathbf{r}$ & $\mathbf{p}$ \\
\hline Distance to health service & -0.41 & $<0.001$ \\
Family income & 0.74 & $<0.001$ \\
\hline
\end{tabular}

Table 4 shows that there was a significant relationship between distance $(\mathrm{r}=0.41 ; \mathrm{p}$ $<0.001)$ and family income ( $\mathrm{r}=0.471 ; \mathrm{p}$ $<0.001$ ) with the frequency of use of health services.

\section{MultivariateAnalysis}

Table 3 showed the results of a multiple linear regression. Table 3 showed that BPJS health insurance $(b=-1.07 ; 95 \% \mathrm{CI}=-1.53$ dence with the value $(\mathrm{b}=-11.61 ; 95 \% \mathrm{CI}=-$ 4.51 to $3.20 ; \mathrm{p}<0.001)$ on the frequency of use of health services.

Table 3. The results of multivariate analysis

\begin{tabular}{|c|c|c|c|c|}
\hline \multirow{2}{*}{ Independent Variable } & \multirow{2}{*}{ b } & \multicolumn{2}{|c|}{$95 \%$ CI } & \multirow[b]{2}{*}{$\mathbf{p}$} \\
\hline & & Lower limit & Upper limit & \\
\hline $\begin{array}{l}\text { BPJS health insurance } \\
\text { status }\end{array}$ & -1.07 & -1.53 & -0.60 & $<0.001$ \\
\hline Age & 0.08 & 0.06 & 0.09 & $<0.001$ \\
\hline Family Income & $8.409 \mathrm{E}-7$ & 0.00 & 0.00 & 0.001 \\
\hline Residence & 0.90 & 0.33 & 1.47 & 0.002 \\
\hline Distance & -0.06 & -0.07 & -0.04 & $<0.001$ \\
\hline
\end{tabular}

\section{\begin{tabular}{l}
\hline DISCUSSION \\
\hline 1. The differences in membership \\
status of BPJS health insurance on \\
the frequency of health service
\end{tabular} \\ \begin{tabular}{l}
\hline DISCUSSION \\
\hline 1. The differences in membership \\
status of BPJS health insurance on \\
the frequency of health service
\end{tabular} \\ \begin{tabular}{l}
\hline DISCUSSION \\
\hline 1. The differences in membership \\
status of BPJS health insurance on \\
the frequency of health service
\end{tabular} \\ \begin{tabular}{l}
\hline DISCUSSION \\
\hline 1. The differences in membership \\
status of BPJS health insurance on \\
the frequency of health service
\end{tabular} utilization}

The results showed that there was difference in BPJS health insurance status on the frequency health service utilization. BPJS health insurance status with class 1 who paid higher premiums tend to often use health services compared to JK BPJS use health services compared to JK BPJS to $-0.60 ; \mathrm{p}<0.001)$ and distance to health service $(b=-0.06 ; 95 \% \mathrm{CI}=-0.07$ to -0.04 ; $\mathrm{p}<0.001)$ reduced frequency of health service utilization. Age $(b=0.08 ; 95 \% \mathrm{CI}=$ 0.06 to $0.09 ; \mathrm{p}<0.001)$, family income $(\mathrm{b}=$ 8.409E-7; 95\% CI= 0.00 to $0.001 ; \mathrm{p}$ $<0.001$ ), urban residence $(b=0.90 ; 95 \%$ $\mathrm{CI}=0.33$ to $1.47 ; \mathrm{p}=0.002$ ) increased frequency of health service utilization. participants with lower premium. In other words, there is an imbalance in the use of health services for BPJS health insurance participants from three classes.

The results of this study are in line with the study conducted by Xie et al. (2014) which states that inequality in the utilization of health services among patients with chronic non-communicable diseases still occurs, this is motivated by the condition and financial capacity of patients. 
The current insurance scheme is not enough to overcome this injustice.

International evidence shows that people with relatively low economic status often show lower levels of access to health services compared to those who are more affluent especially those with chronic noncommunicable diseases (Jian et al., 2009; Jing et al., 2010).

\section{The differences between the age on the frequency of health service utilization}

The results showed that there was a positive difference between the age of the patient and the frequency of use of health services. In the health service use theory which also states that age is one of the predisposing or internal factors that influence a person's behavior to make use of health services. The older a person is, a person's immune system will decrease and at the age of the elderly the degree of disease experienced will be more severe, the tendency of the elderly will increasingly require health services to cure the disease (Ghazi et al., 2017).

The results of this study are in line with the study by Logen et al. (2015) the study explained that age is one of the factors that can affect the utilization of health services, the relatively older age is very vulnerable to chronic disease (hypertension, coronary heart disease or cancer). Pain caused by age causes the level of utilization of health services, this is due to the fact that at an old age a person has decreased physical endurance, making it more susceptible to exposure to an illness.

\section{The effect of the family income on the frequency health service utili- zation}

The results of the study show that there was a relationship between family income and the frequency of use of health services. The results of the study are in line with the study of Khuong and Anh (2013) which states that high opinion is followed by higher service needs, so that the higher the patient's income, the higher the need for access to health services.

Someone with high income tends to be more courageous to ask for additional actions to be taken against the progress of health and illness, with the consequences of costs and treatment to be borne, whereas someone with low income will be passive or not ask questions and tend to accept well action to be taken (Haviland et al., 2005).

The study results from Khuong and Anh (2013) reinforce this study, in which the researchers say that high income will have higher service needs as well, so the higher the patient's income, the higher the need for access to health services.

\section{Difference between residence and the frequency of health service utilization}

The results showed that there were significant differences between the location of residence and the frequency of use of health services. The health services enjoyed by the community are actually a reflection of the demographic, social and economic characteristics and characteristics of the health system and the environment in which they live (Levesque et al., 2013). Thus the city community which has demographic characteristics, social with economic status was diverse and higher with access to access that was easier than the people in rural areas, so that it is easier to access health services. According to Palutturi (2005), the demand for health services was a desire to be healthier reflected in the behavior of seeking medical help. Therefore, it can be concluded that the high demand of the city community for the implementation of health is in accordance with what is needed and desired by urban patients accompanied by purchasing power, as well as more 
knowledge possessed by urban patients than patients living in rural areas.

\section{The relationship between distance to health center and frequency of health service utilization}

The results of the study indicate that there was a relationship between the distance to the frequency of use of health services. This could be interpreted that distance did not become a barrier for patients to use health services according to their wishes in accordance with the needs for care and services provided by the hospital. Patients tended to prioritize the quality of health services to meet their health needs.

Distance is a location based on geographical standards relating to the location of the patient's residence with health care facilities that could be measured through distance, time and cost of travel.

The results of this study are in line with the study conducted by Ardian et al. (2017), the study said that if public awareness of the importance of health was high, then the distance between the location of residence to the place of health services will not affect people's behavior in utilizing health services, the community would make more efforts and tended to choose health services by considering quality and quality provide health services.

Other supporting factors come from health services that provide convenience in terms of access to health services and guarantee programs with easy access to services in reaching out to the health services provided. This could be interpreted that wherever the location of health services with quality and quality that is maintained will still be reached by the people who need them.

\section{AUTHOR CONTRIBUTION}

$\bar{R}$. Haryo Nugroho collected and analyzed data. Bhisma Murti examined the concept- tual framework and methodology, did data analysis, and interpreted the results of analysis. Arif Suryono suggested the discussion materials on BPJS health insurance.

\section{CONFLICTS OF INTEREST}

No conflicts of interest.

\section{FUNDING AND SPONSORSHIP}

There was no external funding and sponsorship.

\section{ACKNOWLEDGEMENT}

We thank the PKU Muhammadiyah Gamping Hospital, Sleman Yogyakarta, for giving permission to conduct this study. We thank to all patients who participated in this study.

\section{REFERENCE}

$\overline{\text { Abu-Zaineh M, Mataria A, Moatti JP, Ven- }}$ telou B (2011). Measuring and decomposing socioeconomic inequality in healthcare delivery: A microsimulation approach with application to the Palestinian conflict-affected fragile setting. Social Science \& Medicine 72(2):133-41.

Adib M (2009). Cara Mudah Memahami dan Menghindari Hipertensi Jantung dan Stroke (Easy Ways to Understand and Avoid Heart Hypertension and Stroke). Yogyakarta: Dianloka Pustaka Populer.

Andersen RM (1995). Revisiting the behavioral model and access to medical care: does it matter?. Journal of Health and Social Behavior. 36(1): 110. Doi: 10.2307/2137284.

Ardian K, Sulaeman ES, Suryono A (2017). Social economic equity in the utilization of hemodialysis. Journal of Health Policy and Management. 2(1): 28-41. https://doi.org/10.26911/thejhpm.2017.02.01.03. 
Braveman P (2006). Health disparities and health equity: Concepts and Measurement. Annual Review of Public Health. 27:167-94.

Budi U, Sucahya PK, Utami FR (2011). Prioritas dan realitas: mengatasi kesenjangan kaya-miskin di status kesehatan dan akses layanan di Indonesia (Priority and reality: addressing the poor inequality in health status and access to services in Indonesia). Jurnal Internasional untuk Bagian Kesehatan. 10: 47.

Culyer A, Wagstaff A (1993). Equity and equality in health and health care. Journal of Health Economics, 12(4): 431-57.

Cuyler A (2001). Equity - Some theory and its policy implications. Journal of Medicine Ethics. 27(4):275-83

Nababan HY, Hasan M, Marthias T, Dhital R, Rahman A, Anwar I (2018). Trends and inequities in use of maternal health care services in Indonesia, 1986-2012. International Journal of Women Health.2018 (10): 11-24 https://doi.org/10.2147/IJWH.S1448 28.

Jian W, Chan KY, Reidpath DD, Xu L (2009). China's rural-urban care gap shrank for chronic disease patients, but inequities persist. Health Affairs. 29(12): 2189-96. doi: 10.1377/hlthaff.2009.0989.

Jing SS, Yin AT, Meng QY (2010). Study on the equity of the health service utilization of rural chronic patients. Chinese Health Economics. 29(2):35-37

Kemenkes RI (2018). Riset kesehatan dasar (Basic Health Research). Jakarta: Balitbang.

Khoung MN, Anh HTH (2013). Direct and indirect effects of customer satisfaction through product and service quality-A study of Phu Nhuan Jewelry
Stores in Ho Chi Minh City, Vietnam. Journal of Economics, Business and Managemen. 1(3): 285-290.Doi:10.7763/JOEBM.2013.V1.62

Haviland MG, Morales LS, Dial TH, Pincus HA (2005). Race/ethnicity, socioeconomic status, and satisfaction with health care.Am J Med Qual. 20(4): 195-203. doi: 10.1177/1062860605275754 .

Ghazi L, Oparil S, Calhoun DA, Lin CP, Dudenbostel T (2017). Distinctive risk factors and phenotype of younger patients with resistant hypertension: Age is relevant. Hypertension. 69(5): 827835.doi:10.1161/HypertensionAHA.116.08632.

Wang L, Li N, Yao X, Chang G, Zhang D, Heizhati M, Wang M, Luo Q, Kong J (2017). Detection of secondary causes and coexisting diseases in hypertensive patients: OSA and PA are the common causes associated with hypertension. Bio Med Research International.https://doi.org/10.1155/2017/8295010.

Levesque JF, Harris MF, Russell G (2013). Patient-centred access to health care: Conceptualising access at the interface of health systems and population. International Journal for Equity in Health.12:18. doi: 10.1186/1475-927612-18.

Liu GG, Zhaob Z, Caic R, Yamadad T,Yamadae T (2002). Equity in health care access to: assessing the urban health insurance reform in China. Social Science \& Medicine, 55(2004): 1779-1794.

Lubis, Fatmal A (2009). Aplikasi SPSS (Statistical Product and Service Solutions) untuk penyusunan skripsi \& tesis, Medan: USU Press.

Marshall GN, Hays RD (1994). The Patient Satisfaction QuestionnaireShort- 
Form (PSQ-18), RAND, Santa Monica, CA

Mora C, Hort k, Furler j, Licqurish s, Gunn $J$ (2017). Pengalaman pasien menggunakan layanan perawatan primer dalam konteks reformasi cakupan kesehatan universal Indonesia (Experience of patients using primary care services in the context of Indonesia's universal health coverage reform). Asia Pac Med. 16:4.

Murti B (2013). Desain dan ukuran sampel untuk penelitian kuantitatif dan kualitatif di bidang kesehatan (Design and size of samples for quantitative and qualitative research in the health sector). Yogyakarta: Gajah Mada University Press.

Nafsiah M, Surbakti IM, Trihandini I, Elyazar I, Smith KH (2018). Di jalan untuk perawatan kesehatan universal di Indonesia, 1990-2016: Analisis Sistematis Untuk Global Burden of Disease Study 2016: 392.

Novi, Thinni (2013). Analisis vertical equity pada pemanfaatan pelayanan kesehatan (Vertical equity analysis on health service utilization). Jurnal Fakultas Kesehatan Masyarakat. Surabaya: Universitas Airlangga.

Oliver A, Mossialos E (2004). Equity of access to health care: outlining the foundation for action.J Epidemiol Community Health. 58(8): 655-658. doi: 10.1136/jech.2003.017731

Peraturan Presiden Nomor 82 Tahun 2018, tentang Jaminan Kesehatan.

Pallutturi, Sukri (2005). Ekonomi Kesehatan (Health Economics). Penerbit:
Bagian Administrasi dan Kebijakan Kesehatan FKM UNHAS

Plianbangchang S (2018). Universal Health Coverage (UHC). Journal of Health Research. 32(4): 322-324.

Sen A (1999). Principles and Basic Concepts of Equity and Health. Oxford: Oxford University Press.

Thabrany H (2009). Introduksi asuransi kesehatan (Introduction to health insurance). Jakarta: Yayasan Penerbitan Ikatan Dokter Indonesia.

Law of the Republic of Indonesia, Number 40 of 2004. About. National Social Security System.

Law of the Republic of Indonesia, Number 36 of 2009, concerning Health.

Undang-Undang Republik Indonesia Nomor 24 Tahun 2011, Tentang Badan Penyelenggara Jaminan Sosial.

Xie X, Wu Q, Hao Y, Yin H, Fu W, Ning N, $\mathrm{Xu} \mathrm{L}$, Liu C, et al.(2014). Identifying determinants of socioeconomic inequality in health service utilization among patients with chronic noncommunicable diseases in China. Plos One. 9(6): e100231. doi:10.1371/journal.pone.010023.

Yustina L, Balqis, Darmawansyah. (2015). Faktor yang berhubungan dengan pemanfaatan pelayanan kesehatan oleh pemulung di TPA Tamangapa (Factors related to the utilization of health services by scavengers at TPA Tamangapa). Bagian Administrasi Kebijakan Kesehatan Fakultas Kesehatan Masyarakat. UNHAS. 